\title{
Cultivation Effect of Chitinase-Transgenic Cotton on Functional Bacteria and Fungi in Rhizosphere and Bulk Soil
}

\author{
Zahra Sadat Shahmoradi ${ }^{1}$, Masoud Tohidfar ${ }^{2}$, Hasan Marashi ${ }^{1,}{ }^{*}$, Saeid Malekzadeh-Shafaroudi ${ }^{1}$, \\ Ebrahim Karimi ${ }^{3}$ \\ ${ }^{1}$ Department of Biotechnology and Plant Breeding, Faculty of Agriculture, Ferdowsi University of Mashhad, Mashhad, \\ Iran \\ ${ }^{2}$ Department of Plant Biotechnology, Faculty of Bioscience and Biotechnology, Shahid Beheshti University, Tehran, Iran \\ ${ }^{3}$ Agricultural Biotechnology Research Institute of Iran, Agricultural Research, Education and Extension Organization \\ (AREEO), Karaj, Iran
}

* Corresponding author: Hasan Marashi, Department of Biotechnology and Plant Breeding, Faculty of Agriculture, Ferdowsi University of Mashhad, Mashhad, Iran; Telephone: +98-9153114098; E-mail: marashi@um.ac.ir

\begin{abstract}
Background: In consideration for the increasing widespread use of genetically modified (GM) crops, one of the important issues for assessment is the effect of GM crops on soil microbial communities

Objectives: In this study, $T_{2}$ chitinase-transgenic cotton (line \#57) and its non-transgenic line were investigated for bacterial and fungal dynamics during its development stages.

Material and Methods: The assessments were performed by viable plate count and polymerase chain reactiondenaturing gradient gel electrophoresis (PCR-DGGE) assays.

Results: Viable plate count analysis showed an increase in community structures and the number of culturable bacteria in rhizosphere of both transgenic and non-transgenic cultivars as compared to bulk soil. PCR-DGGE confirmed results of viable plate count assays of the changes in bacterial and fungal communities for all cotton development stages in rhizosphere and bulk zones. No significant differences in number of functional bacteria were observed between rhizosphere soil of chitinase transgenic and non-chitinase transgenic cotton at one particular stage.

Conclusions: The results indicated that $\mathrm{T}_{2}$ chitinase-transgenic cotton (line \#57) might have no adverse effects on community structures and total number of culturable bacteria and fungi in the rhizosphere.
\end{abstract}

Keywords: Microorganisms, Genetically-Modified; Microbiota; Rhizosphere

\section{Background}

Nowadays, with the advent of agricultural biotechnology, a wide variety of new transgenic crop plants with higher yields and improved traits such as resistance to pests and pathogens and tolerance to herbicides has been developed. This technology has the capacity to promise a great deal of economic and agronomic benefits in the future. In consideration for the increasing widespread use of genetically modified (GM) crops various ecological concerns are emerging, such as effects on non-target organisms and soil ecosystems especially its microorganism. Among these ecological concerns, one of the important issues for assessment is the effect of GM crops on soil microbial communities (1-3).

Microbial communities play a vital role in several essential processes in soil, e.g. turnover of organic materials, nutrient mineralization, controlling the plant pathogens, and soil structure improvement $(3,4)$. The composition of the rhizosphere microflora is a consequence of interactions between root exudates, soil and environmental conditions $(5,6)$. Qualitative and quantitative characteristics of root exudation can profoundly modify the structural and functional diversity of the rhizosphere microbial communities (1, 7-9). The presence of an extra protein in the root exudate can have potential influence on the microbial community in the rhizosphere $(3,10-13)$. Our knowledge of soil microbial diversity is limited in part because many groups of microbes are not cultivable in the laboratory conditions (14). Approximately $1 \%$ of the soil bacterial population can be cultured by standard laboratory practices $(15,16)$. The most knowledge on 
natural microbial community composition has been derived from indirect microbiological techniques. It is now recognized among microbiologists that only a small fraction of all bacteria have been isolated and characterized. Nowadays, microbiologists use the molecular, "culture independent" technologies like DGGE (Denaturing Gradient Gel Electrophoresis) to fill this void $(12,17)$.

\section{Objectives}

The aim of this study was to assess the effects of $\mathrm{T}_{2}$ chitinase-transgenic cotton on soil microbial communities (bacteria and fungi) under greenhouse conditions. For this purpose, DGGE and viable plate count assays were used to analyze the effects of chitinase-transgenic cotton on soil microbial community composition. DGGE was performed on $16 \mathrm{~S}$ rRNA gene and 18S rRNA gene in bacteria and fungi, respectively. The results will help to explore the potential environmental risk assessment of chitinasetransgenic cottons on the soil ecosystem.

\section{Materials and Methods}

\subsection{Soil and Plant Materials}

Soil was collected from the top layer $(0-20 \mathrm{~cm})$ of a cotton field in Varamin, Iran, where no transgenic cotton had ever been planted. The soil was dispensed to the pot and transferred to transgenic greenhouse of Agricultural Biotechnology Research Institute of Iran (ABRII). $T_{2}$ chitinase-transgenic cotton, line \#57 (18, $19)$, was used in the test material.

\subsection{Experimental Design and Soil Sampling}

Transgenic and non-transgenic cotton seeds were planted in completely randomized design (CRD) arrangement with four replications (each replication was mixed of three cotton rhizospher soil) into the pots under controlled temperature, natural light condition, and irrigated 3 times a week. Soil samples (four replicates) were collected from rhizosphere and bulk zones at different developmental stages i.e. seedling, squaring, flowering, and boll. All samples were stored immediately at $-20^{\circ} \mathrm{C}$ for further analyses.

\subsection{Viable Plate Count Assays}

Total bacteria were enumerated using a serial dilution method (20). One gram of sample was suspended in 10 $\mathrm{ml}$ sterile water, shaken for $15 \mathrm{~min}$ at $220 \mathrm{rpm}$, and 10fold serially diluted. The colony forming units (CFU) of bacteria were determined by spreading $100 \mu \mathrm{L}$ of the diluted samples on appropriate culture media (Tryptic Soy Agar, TSA for bacteria) with two replications. Plates were incubated at $28^{\circ} \mathrm{C}$ for 3 days and then colonies were counted visually to estimate CFU of total bacteria(21). This method was also used to enumerate the three culturable functional bacteria nitrogen-fixing, potassium-dissolving and inorganic phosphate- dissolving in the rhizosphere by culturing in appropriate culture media. The specific media were used to determine different bacteria types $\left(\mathrm{I}^{-1}\right.$ in each case): nitrogen-fixing bacteria ( $10.0 \mathrm{~g}$ glucose, $0.2 \mathrm{~g} \mathrm{KH}_{2} \mathrm{PO}_{4}$,

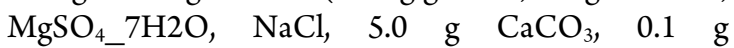
$\mathrm{CaSO}_{4} 2_{2} \mathrm{H}_{2} \mathrm{O}, 15 \mathrm{~g}$ agar, $\mathrm{pH}$ 7.0); inorganic phosphatedissolving bacteria ( $10.0 \mathrm{~g}$ glucose, $0.5 \mathrm{~g}$ yeast extract, $0.1 \mathrm{~g} \mathrm{CaCl}_{2}, 0.3 \mathrm{~g} \mathrm{MgSO}_{4} \_7 \mathrm{H}_{2} \mathrm{O}, 15 \mathrm{~g}$ agar, and $2.5 \mathrm{~g}$ $\mathrm{Ca}_{3}\left(\mathrm{PO}_{4}\right)_{2} \mathrm{pH} 7.2$; (22); and potassium-dissolving bacteria (10.0 g sucrose, $5.0 \mathrm{~g} \mathrm{CaCO} 3,0.5 \mathrm{~g} \mathrm{K2HPO} 4$, $0.5 \mathrm{~g}(\mathrm{NH} 4) 2 \mathrm{SO} 4,0.2 \mathrm{~g} \mathrm{MgSO} 4 \_7 \mathrm{H} 2 \mathrm{O}, 15 \mathrm{~g}$ agar, $\mathrm{pH}$ $7.2-7.4$; (10)).

\subsection{DNA Extraction and PCR Amplification}

Total genomic DNA was extracted from $200 \mathrm{mg}$ of rhizosphere and bulk soil (4 replicate soil samples were mixed) with the PowerSoil ${ }^{\otimes}$ DNA Isolation Kit, based on the manufacturer's instructions. The quality of genomic DNA was checked through $1 \%$ agarose gels and photographed under UV light. The primer pair F357 -GC/R518 (5'-GC-clampCCTACGGGAGGCAGCAG-3' and 5'ATTACCGCGGCTGCTGG-3', respectively), was used to amplify $16 \mathrm{~S}$ rRNA fragment of bacteria community in rhizosphere and bulk soil samples (23). A group-specific primer, Fung-GC and NS1 (5'-GCclamp-ATTCCCCGTTACCCGTTG-3' and 5'GTAGTCATATGCTTGTCTC-3', respectively), was also used to amplify $18 \mathrm{~S}$ rRNA fragment of fungi community (24). In both cases, the forward primer contained a GC clamp (5'CGCCCGCCGCGCGCGGCGGGCGGGGCGGGG GCACGGGGGG-3') to facilitate separation of the amplicons in a DGGE process. For $16 \mathrm{~S}$ rRNA, the PCR was performed with the following program: $5 \mathrm{~min}$ at $95^{\circ} \mathrm{C}$, followed by 35 cycles at $94^{\circ} \mathrm{C}$ for $60 \mathrm{~s}, 51^{\circ} \mathrm{C}$ for 60 $\mathrm{s}$, and $72^{\circ} \mathrm{C}$ for $30 \mathrm{~s}$, with a final extension at $72^{\circ} \mathrm{C}$ for 10 min and for $18 \mathrm{~S}$ rRNA, $3 \mathrm{~min}$ at $94^{\circ} \mathrm{C}$ followed by 30 cycles of $94^{\circ} \mathrm{C}$ for $1 \mathrm{~min}, 50^{\circ} \mathrm{C}$ for $40 \mathrm{~s}$, and $72^{\circ} \mathrm{C}$ for 50 $\mathrm{s}$ and a final extension at $72^{\circ} \mathrm{C}$ for $10 \mathrm{~min}$. PCR products were confirmed by electrophoresis on $1.5 \%$ agarose gels and ethidium bromide staining.

\subsection{Denaturing Gradient $\mathrm{Gel}$ Electrophoresis (DGGE)}

The analysis was carried out with DCode System (BioRad, Milan, Italy) on an $8 \%$ polyacrylamide gel (acrylamide/ bis ratio, 37.5:1), under denaturation conditions (urea $7 \mathrm{M}$ and $40 \%$ formamide with a denaturing gradient ranging from 20 to $70 \%$ ); the gels were run in $1 \mathrm{x}$ TAE buffer at $120 \mathrm{~V}$ and a temperature of $60^{\circ} \mathrm{C}$ for 5 hours. The gels were immediately stained with $25 \mu \mathrm{l}$ of $10 \mathrm{mg} / \mathrm{ml}$ ethidium bromide $(50 \mu \mathrm{g} / \mathrm{ml})$ in sterile water for $30 \mathrm{~min}$ in darkness and then photographed under UV light. Cluster analysis of DGGE banding patterns were performed by using the Dice coefficient for similarity matrix and the unweighted pair group method with mathematical average 
(UPGMA) using NTSYS-pc software package, after band detection.

\subsection{Data Analysis}

Statistical analyses for microbial counts ( $\log _{10} \mathrm{CFU}$ ) were done by one-way analysis of variance (ANOVA) and the Duncan test at the 5\% level with Excel and SAS software.

\section{Results}

4.1. Viable Plate Count Assays

\subsubsection{Total Bacterial Population in Rhizosphere and} Bulk Soil

The analysis of data revealed no significant differences in bacterial population size in rhizosphere and bulk soil between transgenic and non-transgenic cotton $(\mathrm{P}>$ 0.05 ) (table 1). There were significant differences in bacterial population size in rhizosphere soil among growth stages in both transgenic and non-transgenic plants, but not for bulk soil (Fig.1). The maximum population of rhizospheric bacteria was detected at the squaring stage of cottons and then decreased in flowering and boll development stages in both transgenic and non-transgenic samples.

\begin{tabular}{|c|c|c|c|c|}
\hline Source & MS & Fvalue & Probability & Significance \\
\hline \multicolumn{5}{|l|}{ Total bacteria } \\
\hline variety & 0.001 & 0.001 & 0.9206 & ns \\
\hline Error & 0.0004 & & & \\
\hline Growth stage & 0.882 & 453.42 & 0.0001 & s \\
\hline \multicolumn{5}{|c|}{ Potassium-dissolving bacteria } \\
\hline variety & 0.073 & 0.4 & 0.533 & ns \\
\hline Error & 0.038 & & & \\
\hline Growth stage & 1.463 & 226.96 & $<0.0001$ & s \\
\hline \multicolumn{5}{|c|}{ Nitrogen-fixing bacteria } \\
\hline variety & 0.045 & 0.69 & 0.4118 & ns \\
\hline Error & 0.0042 & & & \\
\hline Growth stage & 0.499 & 128.44 & $<0.0001$ & s \\
\hline \multicolumn{5}{|c|}{ Inorganic phosphate-dissolving bacteria } \\
\hline variety & 0.00003 & 0 & 0.9730 & ns \\
\hline Error & 0.0049 & & & \\
\hline Growth stage & 0.245 & 144.7 & $<0.0001$ & $\mathrm{~s}$ \\
\hline
\end{tabular}

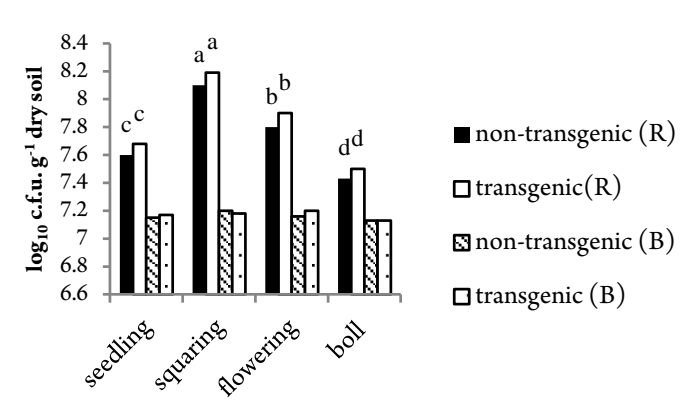

Figure 1. The population of bacteria in rhizosphere and bulk soil at different growing stages of cotton. rhizosphere (R) and bulk (B) soil.

\subsubsection{Functional Bacteria Population}

The results of functional bacteria were not variable. There were no significant differences in rhizospheric potassium-dissolving bacteria between transgenic and non-transgenic cotton at seedling, squaring, flowering and boll development stages (Table 1). The maximum population size of potassium-dissolving bacteria was observed during squaring stage of cottons. The number of rhizospheric potassium-dissolving bacteria of transgenic and non-transgenic was returned to the same levels, with no significant diferrences, at the boll development stage (Fig. 2a). Significant differences in nitrogen-fixing bacteria population size was detected at various growth stages (Table 1). At the boll development stage, the number of nitrogen-fixing bacteria in rhizosphere soil of transgenic and non- transgenic cotton did not differ significantly (Fig. $2 \mathbf{b}$ ). There were no significant differences in the inorganic phosphate-dissolving bacteria population size in rhizosphere soil of transgenic and non-transgenic cotton (Table 1). Nonetheless, there were significant differences in some growth stages (Fig. 2c).

\subsection{Denaturing Gradient $\mathrm{Gel}$ Electrophoresis (DGGE)}

DGGE banding patterns were slight variation among chitinase-transgenic cotton and control at the different growth stage, whereas the same dominant bands were found between chitinase-transgenic and non-transgenic cotton at the same growth stage in both PCR products of $16 \mathrm{~S}$ rRNA and 18S rRNA (Fig. 3) of rhizosphere samples. Based on the bacterial and fungal DGGE profiles (Fig. 3), the cluster analysis showed that chitinase-transgenic cotton and non-transgenic cotton at seedling formed single cluster, and the remaining samples fell into another cluster (Fig. 4). According to the results there are no significant differences between microbial dynamic of transgenic cotton and nontransgenic cotton during 4 growth stages.

\section{Discussion}

Our results showed significant variations $(\mathrm{P} \leq 0.05)$ in bacterial population size of rhizosphere soil in both transgenic and non-transgenic cottons during different 
growth stages. Though, no significant variations were observed in bulk soil. Nevertheless, there were no significant differences in total microbial population size in rhizosphere soil between transgenic cotton and nontransgenic parents.
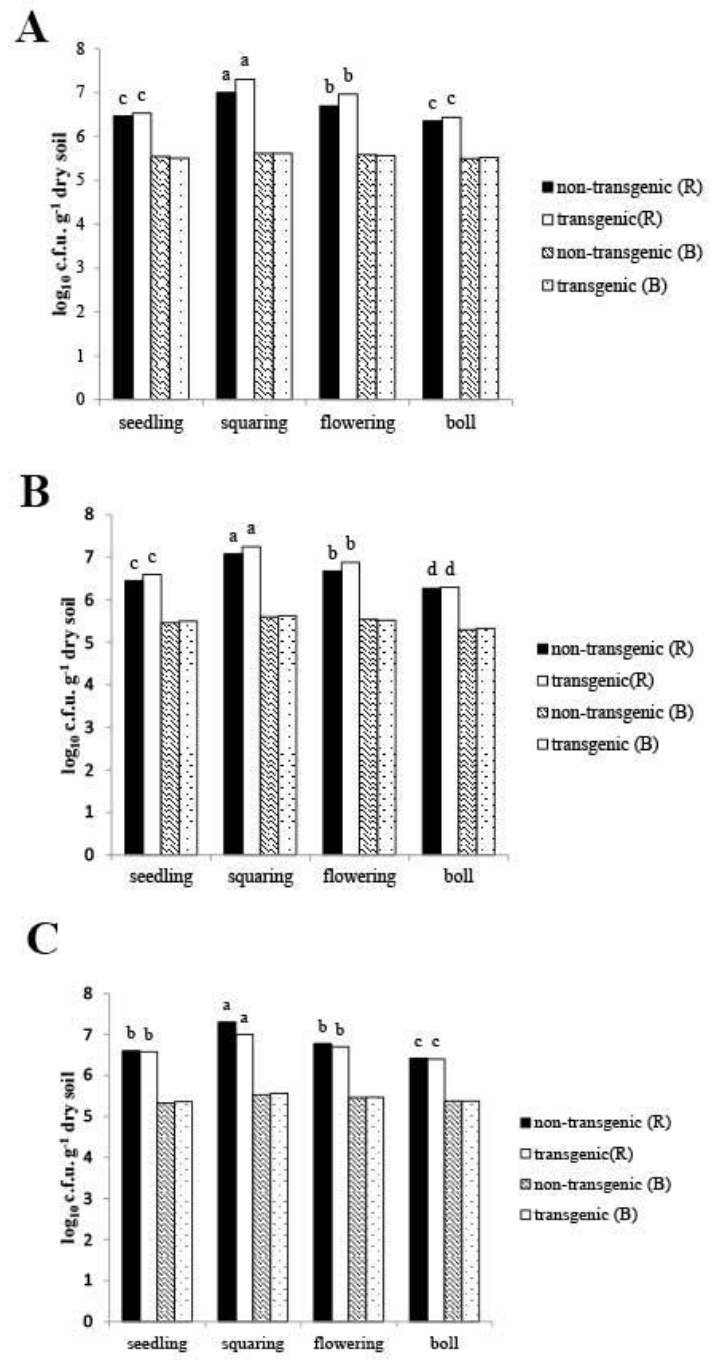

Figure 2. The population of functional bacteria in rhizosphere and bulk soil at different growing stages of cotton. A) potassium-dissolving bacteria, B) nitrogen-fixing bacteria, C) inorganic phosphatedissolving bacteria. rhizosphere (R) and bulk (B) soil.

These results are in accordance with those of Wang, Shen (16), who reported that 1-year-old chitinasetransgenic (McChit1) tobacco ( $\mathrm{T}$-Chit) were non-toxic to the number of cultivable bacteria and fungi population in studied purple soil during tobacco growth. In addition, no significant differences were observed between rhizosphere soil of chitinase transgenic and non-chitinase transgenic cotton in the numbers of culturable potassium-dissolving bacteria, nitrogenfixing bacteria and inorganic phosphates-dissolving bacteria during same stages. Similarly, Hu et al. (2008) found no significant differences between rhizospheric $\mathrm{Bt}$ and non-Bt cotton soil in the number of culturable functional bacteria (nitrogen-fixing bacteria, potassium- dissolving bacteria and organic and inorganic phosphates dissolving bacteria) during the four sampling stages in the four fields.

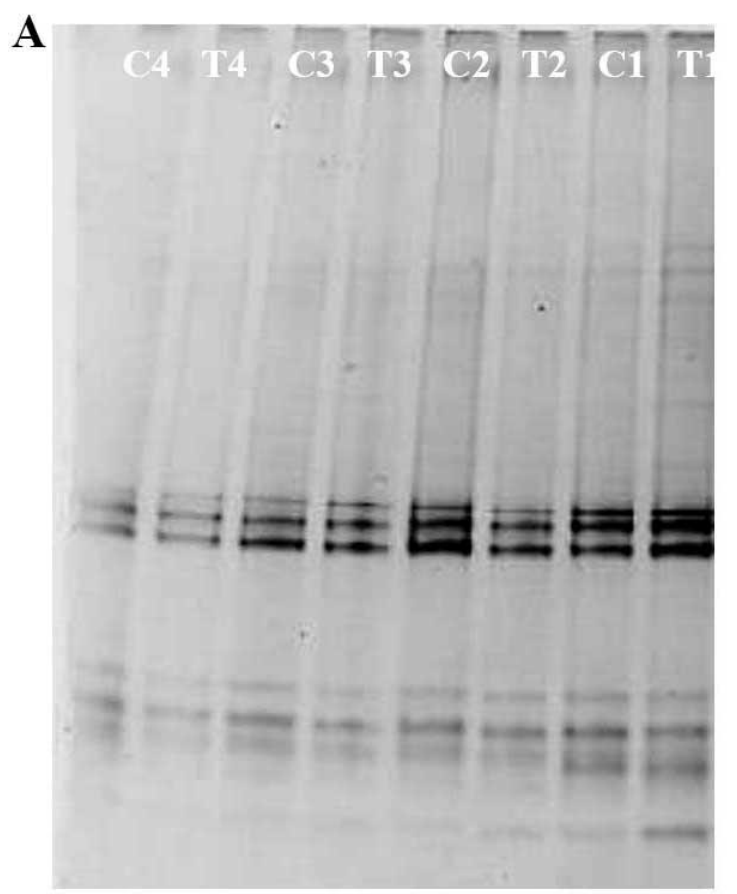

B

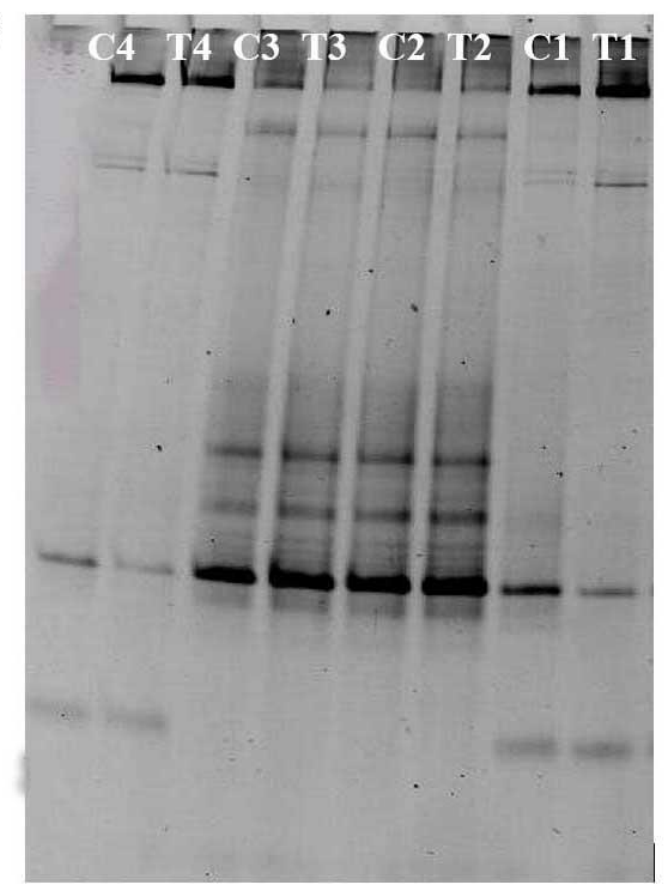

Figure 3. DGGE profiles of amplified 16S rRNA regions obtained from rhizosphere soil A) and 18S rRNA regions obtained from rhizosphere soil B) in different growth stages of transgenic and non-transgenic cotton. $\mathrm{T}$ : transgenic cotton, $\mathrm{C}$ : non-transgenic cotton, numbers 1 up to 4 , four growth stage of cotton: seedling, squaring, flowering and boll development stage.

Icoz and Stotzky (2008) also reported there were no statistically significant differences in microorganism's populations, the enzymes activity, and the $\mathrm{pH}$ between $\mathrm{Bt}$ and non-Bt corn soils after 4 sequential years of corn 
planting. Meanwhile, Li, Liu (25) demonstrated that long-term cultivation of Bt transgenic cottons do not exert any significant changes on community structure of bacteria, actinomycetes and fungi.

Rui, Yi (10) indicated that there were no correlations between $\mathrm{Bt}$ toxin levels and number of the functional bacteria. Similarly, Bt toxin may not directly change the numbers of functional bacteria in the rhizosphere (10). $\mathrm{Li}$, Liu (25) reported that the presence of Bt-transgenic oilseed rape in wild mustard populations had no direct effects on the rhizosphere nematode and microbial communities.
A

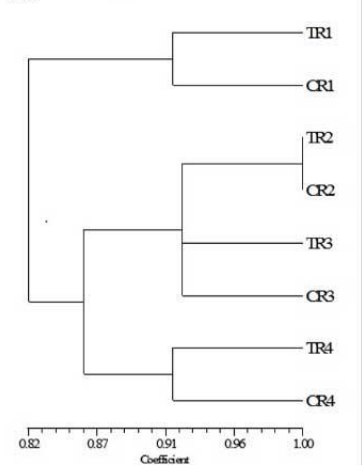

B

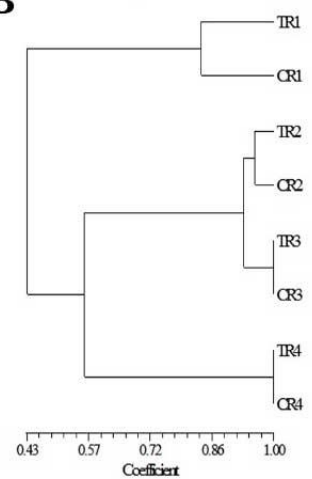

Figure 4. Cluster analysis of DGGE profiles for bacteria A), fungi B) from rhizosphere soil in different growth stages of transgenic and nontransgenic cotton. $\mathrm{T}$ : transgenic cotton, $\mathrm{C}$ : non-transgenic cotton, $\mathrm{R}$ numbers 1 up to 4 , four growth stage of cotton: seedling, squaring, flowering and boll development stage. The dendrogram was created by using the similarity matrix based on Dice coefficients and unweighted pair group method with arithmetic averages (UPGMA).

The diversity of bacteria and fungi in rhizosphere was determined by PCR-DGGE. DGGE results showed similar banding patterns for PCR products of $16 \mathrm{~s}$ rRNA and $18 \mathrm{~s}$ rRNA of rhizosphere and bulk samples. Cluster analysis revealed that the effect of cotton development growth stages was more powerful than the effect of chitinase transgenic plants on the soil microbial communities. This means chitinase cotton had no negative effect on microbial population in soil compared to control cotton. Likewise, Zhang et al. (26) suggested there were significant developmental variations related to cotton growth stages in the number of eubacteria, fungi and actinomycete of rhizosphere soil. However, there was no significant difference in microbial population size and community structures in rhizosphere soil between Monsanto's Bt-cotton NC 33B and non-transgenic cotton.

\section{Conclusions}

In our study, the results indicated that bacterial communities in rhizosphere soil were modified considerably by the growth stage, but there was no significant difference between microflora of chitinase and control cotton rhizosphere. It is noticeable that alteration in soil microbial community had several reasons such as, the effect of climate and season, soil type and structure, plant species, and plant developmental stage (6). Similarly many other previous studies, revealed that the effect of transgenic crops were minor, transient or no significant on microbial populations in rhizosphere soil (2-4, 8, 27-30).

However, to obtain great knowledge or insight about the effect of transgenic plants on microbial community and take a more complete notion about microbial diversity, we need to use other technology like Next Generation Sequencing (NGS) approaches for meta-genome sequencing.

\section{Acknowledgement}

This study was supported by the Agriculture Biotechnology Research Institute of Iran (ABRII). We would like to thank all our colleagues in the Department of Genetic Engineering and Microbial Biotechnology and Biosafety Department of ABRII for their support and technical collaborations.

\section{References}

1. Bruinsma M, Kowalchuk G, Van Veen J. Effects of genetically modified plants on microbial communities and processes in soil. Biol Fertil oils. 2003;37(6):329337.

2. Liu B, Zeng Q, Yan F, Xu H, Xu C. Effects of transgenic plants on soil microorganisms. Plant Soil. 2005;271(1):1-13. doi: 10.1007/s11104-004-1610-8

3. Icoz I, Stotzky G. Fate and effects of insect-resistant Bt crops in soil ecosystems. Soil Biol Biochem. 2008;40(3):559-586.

doi: 10.1016/j.soilbio.2007.11.002

4. Wei M, Tan F, Zhu H, Cheng K, Wu X, Wang J, et al. Impact of Bt-transgenic rice (SHK601) on soil ecosystems in the rhizosphere during crop development. Plant Soil Environ. 2012;58(5):217-223. doi: 10.17221/627/2011-PSE

5. Giovannetti M, Sbrana C, Turrini A, editors. The impact of genetically modified crops on soil microbial communities. Rivista di Biologia/Biology Forum; 2005.

6. Berg G, Smalla K. Plant species and soil type cooperatively shape the structure and function of microbial communities in the rhizosphere. FEMS Microbiol Ecol. 2009;68(1):1-13. doi: 10.1111/j.15746941.2009.00654.x pmid: 19243436

7. Hinsinger P, Bengough AG, Vetterlein D, Young IM. Rhizosphere: biophysics, biogeochemistry and ecological relevance. Plant Soil. 2009;321(1-2):117152. doi: $10.1007 / \mathrm{s} 11104-008-9885-9$

8. Zaman M, Mirza MS, Irem S, Zafar Y. A Temporal Expression of Cry1Ac Protein in Cotton Plant and its Impact on Soil Health. Int J Agricult Biol. 2015;17(2).

9. Brusetti L, Francia P, Bertolini C, Pagliuca A, Borin S, Sorlini C, et al. Bacterial communities associated with the rhizosphere of transgenic Bt 176 maize (Zea mays) and its non transgenic counterpart. Plant Soil. 2005;266(1-2):11-21. doi: 10.1007/s11104-005-5399$\mathrm{x}$

10. Rui Y-K, Yi G-X, Zhao J, Wang B-M, Li Z-H, Zhai Z-X, et al. Changes of $\mathrm{Bt}$ toxin in the rhizosphere of 
transgenic Bt cotton and its influence on soil functional bacteria. World J Microbiol Biotechnol. 2005;21(6):1279-1284. doi: 10.1007/s11274-0052303-z

11. Xue K, Luo HF, Qi HY, Zhang HX. Changes in soil microbial community structure associated with two types of genetically engineered plants analyzing by PLFA. J Environ Sci (China). 2005;17(1):130-134. pmid: 15900775

12. Filion M. Do transgenic plants affect rhizobacteria populations? Microb Biotechnol. 2008;1(6):463-475. doi: $\quad 10.1111 / j .1751-7915.2008 .00047 . x \quad$ pmid: 21261867

13. Chen ZH, Chen LJ, Wu ZJ. Relationships among persistence of Bacillus thuringiensis and Cowpea trypsin inhibitor proteins, microbial properties and enzymatic activities in rhizosphere soil after repeated cultivation with transgenic cotton. Appl Soil Ecol. 2012;53:23-30. doi: 10.1016/j.apsoil.2011.10.019

14. Schmidt TM, Waldron C. Microbial diversity in soils of agricultural landscapes and its relation to ecosystem function. The ecology of agricultural landscapes: longterm research on the path to sustainability. New York: Oxford University Press; 2015. 135-157 p.

15. Torsvik V, Ovreas L. Microbial diversity and function in soil: from genes to ecosystems. Curr Opin Microbiol. 2002;5(3):240-245. pmid: 12057676

16. Wang B, Shen H, Yang X, Guo T, Zhang B, Yan W. Effects of chitinase-transgenic (McChit1) tobacco on the rhizospheric microflora and enzyme activities of the purple soil. Plant Soil Environ. 2013;59:241-246. doi: 10.17221/704/2012-PSE

17. Hirsch PR, Mauchline TH, Clark IM. Cultureindependent molecular techniques for soil microbial ecology. Soil Biol Biochem. 2010;42(6):878-887. doi: 10.1016/j.soilbio.2010.02.019

18. Tohidfar M, Mohammadi M, Ghareyazie B. Agrobacterium-mediated transformation of cotton (Gossypium hirsutum) using a heterologous bean chitinase gene. Plant Cell Tissue Organ Cult. 2005;83(1):83-96. doi: 10.1007/s11240-004-6155-2

19. Tohidfar M, Hossaini R, Bashir NS, Meisam T. Enhanced Resistance to Verticillium dahliae in Transgenic Cotton Expressing an Endochitinase. Czech $J$ Genet Plant Breed. 2012;48(1):33-41. doi: 10.17221/89/2011-CJGPB

20. Ben-David A, Davidson CE. Estimation method for serial dilution experiments. J Microbiol Methods. 2014;107:214-221. doi: 10.1016/j.mimet.2014.08.023 pmid: 25205541

21. Karimi E, Sadeghi A, Abbaszade Dehaji P, Dalvand Y,
Omidvari M, Kakuei Nezhad M. Biocontrol activity of salt tolerant Streptomyces isolates against phytopathogens causing root rot of sugar beet. Biocont Sci Technol. 2012;22(3):333-349. doi: 10.1080/09583157.2012.658552

22. Hu H-Y, Liu X-X, Zhao Z-W, Sun J-G, Zhang Q-W, Liu $X-Z$, et al. Effects of repeated cultivation of transgenic Bt cotton on functional bacterial populations in rhizosphere soil. World J Microbiol Biotechnol 2009;25(3):357-366. doi: 10.1007/s11274-008-98998

23. Yuan $\mathrm{X}, \mathrm{Xu}$ J, Chai $\mathrm{H}$, Lin $\mathrm{H}$, Yang $\mathrm{Y}$, Wo $\mathrm{X}$, et al. Differences of rhizo-bacterial diversity and the content of peimine and peiminine of Fritillaria thunbergii among different habits. $J$ Med Plants Res. 2010;4(6):465-470.

24. Das M, Royer TV, Leff LG. Diversity of fungi, bacteria, and actinomycetes on leaves decomposing in a stream. Appl Environ Microbiol. 2007;73(3):756-767. doi: 10.1128/AEM.01170-06 pmid: 17142366

25. Liu Y, Li J, Neal Stewart C, Jr., Luo Z, Xiao N. The effects of the presence of Bt-transgenic oilseed rape in wild mustard populations on the rhizosphere nematode and microbial communities. Sci Total Environ. 2015;530-531:263-270. doi: 10.1016/j.scitotenv.2015.05.073 pmid: 26047860

26. Zhang Y-J, Xie M, Wu G, Peng D-L, Yu W-B. A 3-year field investigation of impacts of Monsanto's transgenic Bt-cotton NC 33B on rhizosphere microbial communities in northern China. Appl Soil Ecol. 2015;89:18-24. doi: 10.1016/j.apsoil.2015.01.003

27. Saxena D, Stotzky G. Bacillus thuringiensis (Bt) toxin released from root exudates and biomass of Bt corn has no apparent effect on earthworms, nematodes, protozoa, bacteria, and fungi in soil. Soil Biol Biochem. 2001;33(9):1225-1230. doi: 10.1016/S00380717(01)00027-X

28. Castaldini M, Turrini A, Sbrana C, Benedetti A, Marchionni M, Mocali S, et al. Impact of Bt corn on rhizospheric and soil eubacterial communities and on beneficial mycorrhizal symbiosis in experimental microcosms. Appl Environ Microbiol. 2005;71(11):6719-6729. doi: 10.1128/AEM.71.11.6719-6729.2005 pmid: 16269702

29. Turrini A, Sbrana C, Nuti MP, Pietrangeli BM, Giovannetti M. Development of a model system to assess the impact of genetically modified corn and aubergine plants on arbuscular mycorrhizal fungi. Plant Soil. 2005;266(1-2):69-75. doi: 10.1007/s11104-0054892-6

30. Liu W, Lu HH, Wu W, Wei QK, Chen YX, Thies JE. Transgenic Bt rice does not affect enzyme activities and microbial composition in the rhizosphere during crop development. Soil Biol Biochem. 2008;40(2):475-486. doi: 10.1016/j.soilbio.2007.09.017 